\title{
COMO NASCEM AS IMAGENS? UM ESTUDO DE HISTÓRIA VISUAL
}

\author{
How are images born? A study of visual history
}

Ana Maria Mauad*

\begin{abstract}
RESUMO
O artigo propõe uma abordagem de história visual, em que se acompanha a trajetória da fotografia produzida pelo fotógrafo francês Marc Riboud, em 1967. Adota-se uma perspectiva não linear dos tempos históricos para analisar os percursos da imagem e a elaboração de representações visuais na história. A análise, apoiada na antropologia da imagem de Hans Belting, acompanha, nas diferentes culturas visuais, o surgimento de imagens semelhantes.
\end{abstract}

Palavras-chave: fotografia; tempos históricos; cultura visual.

\begin{abstract}
This article proposes an approach for visual history, in which, it is fallowed the trajectory of the photograph produced by French photographer, Marc Riboud, in 1967. It is adopted a non linear perspective of historical time to analyze the routes of the image and the historical elaboration of the visual representations. The analysis, based on Hans Belting's Anthropology of image, fallows in different visual cultures the birth of similar images.
\end{abstract}

Keywords: photography; historical time; visual culture.

* Doutora em História pela UFF. Professora do Departamento de História da UFF, Coordenadora do Programa de Pós-Graduação em História da UFF, Pesquisadora do CNPq e Cientista do Nosso Estado, Faperj. Este texto insere-se no projeto de pesquisa "O olhar engajado: prática fotográfica e os sentidos da História”, CNPq, 2011-2015, desenvolvido junto ao Laboratório de História Oral e Imagem da Área de História da UFF; anammauad@uol.com.br 


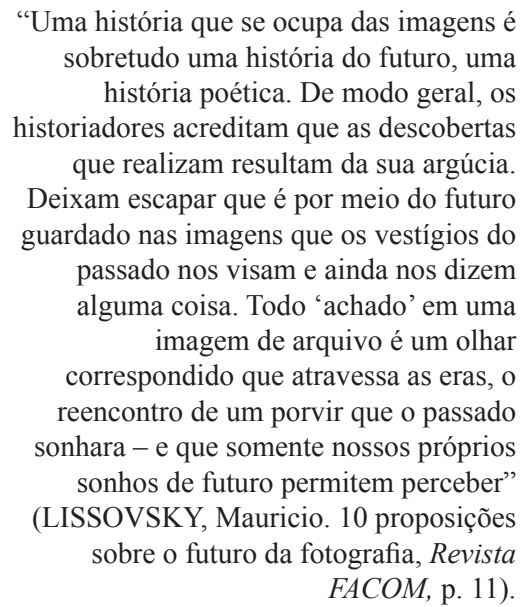

Imagens como flashes recompõem os acontecimentos contemporâneos. Uma mulher de olhar perdido segura uma criança, rodeada por seus outros filhos, só ela olha para a câmera. Uma menina corre de braços abertos, com o corpo desnudo pelas chamas do napalm, numa estrada com mais outras pessoas. Um presidente perde o equilíbrio e troca as pernas em passo em falso. Os exemplos poderiam se multiplicar, mas estes já servem para ponderar sobre a relação entre fotografia e história.

Em "Palavras de luz", artigo de título sugestivo, Eduardo Cadava analisa a quinta tese sobre História de Walter Benjamim, em que o filósofo utiliza-se de referências visuais para definir o passado como imagem que só pode ser apreendida como relâmpago, ou ainda como flash, no momento da aparição, mas sendo impossível recuperá-lo a não ser como imagem daquilo que deixou de existir. Essa tensão entre o que aconteceu e o que aconteceria também está presente na fotografia, espécie de condensação de tempos que já não existem, mas permanecem estáticos na superfície fotográfica, como se previssem o futuro.

1 CADAVA, Eduardo. Words of Light: Theses on the Photography of History. In: PETRO, Patrice (Ed.). Fugitive Images: From photography to video. Indianapolis: Indiana University Press, 1995. p. 221-244. 
Cadava, como lembra Lissovsky², ousou dizer que não há história que não seja fotográfica. Isso porque, ao interpretar os escritos de Benjamin sobre História, Cadava a relaciona com imagem, especificamente, a fotográfica. Assim, para Benjamin, as leis da fotografia não somente contam para a força das imagens sobre aquilo que se identifica como "realidade" histórica, mas também o "imagismo ${ }^{3}$ essencial que opera entre o movimento e a constituição da história". ${ }^{4}$ Os elos com o conhecimento potencializam a força da imagem, daí as consequências para os domínios da história e da política. Esse é o motivo pelo qual, segundo Cadava, o materialismo da teoria da história de Benjamin pode ser alegorizado pela imagem fotográfica. Como consequência, "a função da câmera é produzir imagens, a historiografia produzida pela câmera envolve a construção da estrutura fotográfica, que tanto produz como reconfigura a compreensão e significação histórica". ${ }^{5}$

História fotográfica em que os foto-ícones representem a condensação do tempo histórico em acontecimento coloca-se como uma possibilidade a se explorar. Em outros textos, me debrucei sobre a relação entre a imagem fotográfica e a produção do fato histórico, trabalhando com dimensões temporais do acontecimento, bem como as sensibilidades e os sentimentos que envolvem a expressão visual da experiência coletiva com alguns acontecimentos. ${ }^{6}$

A noção de foto-ícone não é consensual nos estudos sobre a fotografia pública e cabe, brevemente, indicar as posições no debate. Os estudos sobre fotografia e acontecimento histórico desenvolvidos nos Estados Unidos, no campo dos estudos da cultura pública e dos meios de comunicação,

2 LISSOVSKY, Mauricio. Dez proposições acerca do futuro da fotografia e dos fotógrafos. Revista FACOM, v. 23, p. 9, $1^{\circ}$ semestre 2011.

3 Essential imagism, expressão utilizada no original em inglês. A utilização do termo - imagism - por Cadava identifica a relação História e imagem ao movimento da poesia inglesa e americana do início do século XX, favorável à precisão das imagens poéticas e à utilização clara e precisa da linguagem, tendência que se opunha ao romantismo e se alinhava ao modernismo internacional. Eduardo Cadava desenvolve seus estudos sobre imagem no âmbito da teoria literária; portanto, ao convocar esse movimento poético para dimensionar a constituição da história (como imagem), opõe a história romântica à moderna na linha do materialismo de Walter Benjamin.

4 CADAVA, op. cit., p. 235.

5 Idem.

6 MAUAD, Ana M. Foto-ícones, a história por detrás das imagens? Considerações sobre a narratividade das imagens técnicas. In: Imagens da História. 1 ed. v. 1. São Paulo: Hucitec, 2008. p. 3366; MAUAD, Ana M. Uma disputa, uma perda e uma vitória: fotografia e a produção do acontecimento histórico na imprensa ilustrada dos anos 1950. In: Comunicação e História: interfaces e novas abordagens. 1 ed. v. 1. Rio de Janeiro: Mauad, 2008. p. 159-189. 
identificam os foto-ícones à experiência política de reconhecimento dos ideais da democracia liberal e da cultura humanista à fotografia pública.

Duas posições ${ }^{7}$ podem ser destacadas: a primeira, defendida por Blake Stimson, atribui à fotografia, principalmente aquela produzida no pós Segunda Guerra Mundial, o papel de eixo ordenador das demandas coletivas em torno da nação como comunidade de sentido, onde se compartilham valores que podem ser estendidos a toda a humanidade. Segundo esse autor, a fotografia poderia vir a se tornar o espaço comum em que se consolidariam as identidades sociais, assumindo o papel antes ocupado pela nação no imaginário ocidental, daí apresentar a ideia de nação fotográfica. ${ }^{8}$

Já na segunda posição, apresentada por Harriman e Lucaites, ${ }^{9}$ a fotografia - na sua expressão de foto-ícone - caracteriza-se pela capacidade de comunicar e de mobilizar valores associados à democracia liberal e à cultura pública, provendo modelos performativos para o exercício da cidadania. Os autores definem foto-ícones como imagens que aparecem na imprensa e nas mídias eletrônica e digital, amplamente reconhecidas e lembradas, e compreendidas por representarem eventos historicamente significativos. $\mathrm{Na}$ audiência provocam respostas emocionais e identificação imediata entre os sujeitos envolvidos e circulam por meios variados. Embora os foto-ícones disseminados pelo fotojornalismo não possuam extensão universal e não se caracterizem, necessariamente, por premiações, mobilizam os ideais de cidadania, da política moderna, da igualdade de direito, das obrigações coletivas. Isso porque criam princípios comuns para a construção da identidade coletiva na cultura pública liberal-democrática. ${ }^{10}$

Ambas as posições associam-se ao estudo da cultura pública na democracia americana moderna, mas esse modelo de cultura possui limitações para a compreensão de outras situações históricas. Portanto, vale indicar a possibilidade de se operar com a noção de foto-ícone por outra perspectiva, a fim de retomar-se o projeto da história fotográfica. Neste estudo, proponho

7 A primeira posição engajada e crítica em relação à defesa incontestável dos valores da democracia liberal representa-se pela reflexão de Blake Stimson; a segunda, tributária da tradição crítica liberal, valoriza a cultura pública e a sua capacidade de promover o consenso, representada pelos escritos de Lucaites e Harriman.

8 STIMSON, Blake. The Pivot of the World: Photography and its Nation. Massachusetts: MIT Press, 2007. Introduction, p. 21.

9 HARIMAN, Robert; LUCAITES, John Louis. No Caption Needed. Chicago: University of Chicago Press, 2007.

10 Ibidem, p. 28 
uma abordagem que se apoia na noção de que todas as imagens possuem uma biografia, ${ }^{11}$ que ensejam trajetórias nem sempre lineares, o que implica afirmar que não existe uma história por detrás das imagens, mas imagens que fazem história. Assim, gostaria de refletir sobre o nascimento de uma imagem e, por meio da sua trajetória, problematizar a ordem dos tempos históricos. O roteiro se inicia em Washington DC, 1967, ruma para as praças e ruas do mundo contemporâneo, notadamente o Brasil em 2013, volta ao passado no século $\mathrm{XV}$ e ruma novamente para o futuro como possibilidade.

\section{Como nascem as imagens? O fotógrafo, a moça e uma flor}

Em uma das sequências do documentário Contacts, coletânea em vídeo organizada pelo fotógrafo e artista Willian Klein (2007), Marc Riboud nos contempla com o relato sobre o nascimento de uma imagem em outubro de 1967:

Atraído pelo rastro de uma causa num momento simples e autoevidente, eu me encontro em Washington, um dia em outubro, 1967. O sol de um verão indiano está brilhando em uma enorme e alegre marcha pela paz no Vietnã. Em centenas e milhares, pretos e brancos, meninas e meninos se atrevem a sitiar o Pentágono, fortaleza símbolo do exército mais poderoso do mundo. Naquele dia, a juventude americana põe uma linda face na América. Fotografo em frenesi. Chega a noite e meus filmes estão quase terminando, quando esta jovem com uma flor, enfrentando baionetas sozinha, desenha o símbolo da juventude americana no meu visor. É a última pose do meu filme, e ela teve sorte, esteve em todo o mundo enquanto outras ficaram no fundo da gaveta.

Agora eu estou relendo esta folha de contato, como um caderno de notas. Deixe-me escolher outra foto. Rostos mascarados e

11 Sobre a possibilidade de biografar imagens, cf. MENESES, Ulpiano T. B. A fotografia como documento: Robert Capa e o miliciano abatido na Espanha: sugestões para um estudo histórico. Tempo, n. 14, p. 131-151. 
baionetas apontadas formam um padrão sinistro nas fotografias. Esta é a cara feroz do governo americano exposta naquele dia. Mas a flor não está lá, somente os homens maus. A primeira escolha foi realmente a certa.
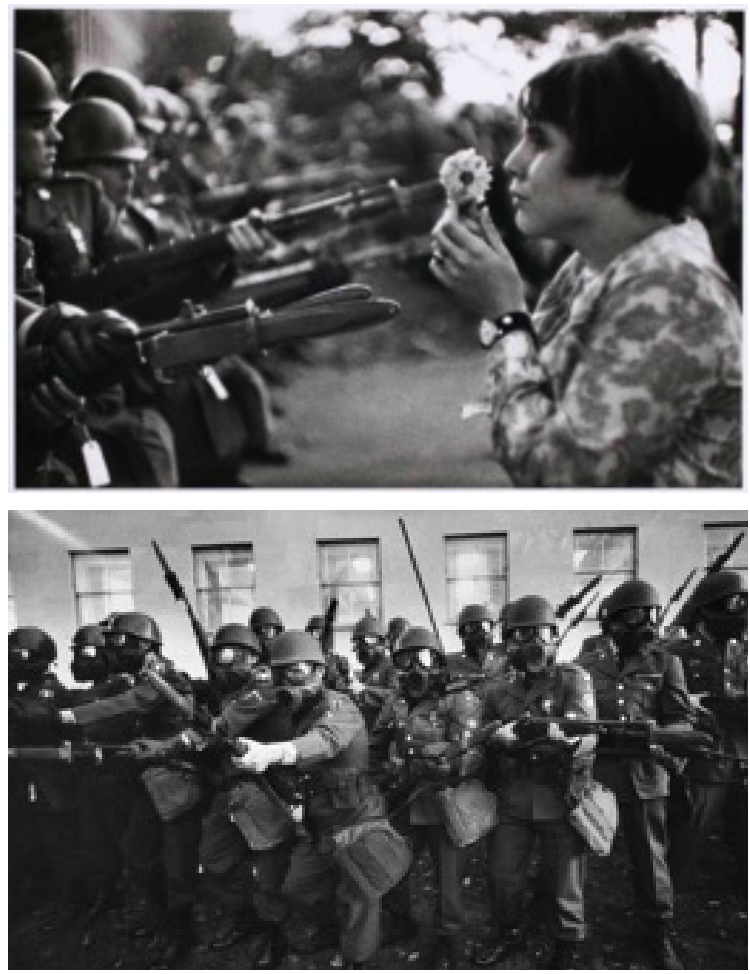

FIGURA 1.

Marc Riboud, fotógrafo documentarista francês, nasceu em Lyon no ano de 1923. Em 1937, aos 14 anos, foi premiado na Exposição Universal de Paris pelas fotografias tiradas por uma Vest-Pocket, que havia ganho de presente de aniversário de seu pai. Combateu como soldado na Segunda Guerra Mundial e depois do conflito ingressou para estudar engenharia na École Centrale de Lyon, terminando o curso em 1948. Paralelamente aos seus estudos, trabalhou como usineiro; entretanto, em uma de suas férias, 
se envolveu com o Festival de Lyon de fotografia. Abandonaria o trabalho na usina e passaria a se dedicar exclusivamente à fotografia.

Em 1953, consegue publicar na Life Magazine uma de suas fotos dos pintores da Torre Eiffel. Na sequência, por convite de Henri Cartier-Bresson e Robert Capa, ingressa na agência Magnum e passa a fotografar intensamente diferentes lugares da Europa. Em 1955, parte rumo ao Oriente Médio e ao Afeganistão, mas desiste da viagem, voltando-se para a Índia, onde permaneceria um ano. Daí parte para uma primeira viagem à China em 1957. Depois de uma estadia de três meses na URSS em 1960, ele cobriu os movimentos de independência da Argélia e da África do Norte. Entre 1968 e 1969, foi repórter fotográfico no Vietnã do Sul e do Norte, onde foi um dos poucos fotógrafos que conseguiu entrar e fotografar. Desde os anos 1980 ele retornou várias vezes ao Oriente e ao Extremo Oriente, produzindo imagens que foram expostas em diferentes partes do mundo, Paris, Londres, Nova York, Pequim, Hong Kong, Bilbao.

Marc Riboud pertence à geração dos concerned photographers, fotógrafos que definiam a prática fotográfica como o engajamento à causa social. O próprio Riboud assim define a experiência como fotógrafo:

$$
\begin{aligned}
& \text { Rather than a profession, photograpty } \\
& \text { has a lways been a passion forme, } \\
& \text { a passion closer to an otsession. } \\
& \text { havarinonf }
\end{aligned}
$$

Durante a Segunda Guerra Mundial, Riboud ingressou nas colunas da resistência francesa em defesa da liberdade e combateu a ocupação ale-

12 "Mais do que uma profissão, fotografia sempre foi para mim uma paixão, quase uma obsessão", citação coletada em http://www.marcriboud.com, em abril de 2010. 
mã na França. Ele sobreviveu à guerra, mas mudou definitivamente a sua forma de olhar o mundo. Depois da guerra, ele continuou perseguindo os conflitos pelo mundo afora. Sua câmera capturava imagens comprometidas com o olhar engajado em causas humanistas, pela liberdade, igualdade e fraternidade dos povos.

Em 1967, as manifestações contra a guerra do Vietnã não representavam excepcionalidade, pois desde 1963 jovens ligados às várias tendências políticas já se posicionavam claramente contra a guerra. As imagens das mobilizações públicas criaram um espaço visual público de protesto composto por fotografias, objetos e registros fílmicos. ${ }^{13}$ Os eventos contra a guerra se alinhavam aos demais protestos espalhados mundo afora, tendo em comum o engajamento da juventude, a ocupação dos espaços públicos e a elaboração de uma economia visual caracterizada pelo trânsito de imagens em distintos suportes: corpos, cartazes, bottons, fotografias, filmes, caricaturas, etc.

Nesse espaço visual, se projetava a opinião pública contra a guerra. Por um lado, embalava-se por signos da cultura pop, do movimento hippie e da luta pelos direitos civis nos Estados Unidos; por outro, essa opinião pública também fermentava-se pelas imagens fotográficas que chegavam, continuamente, do front, o teatro de horrores que a guerra havia criado. A cobertura fotográfica da Guerra do Vietnã, feita por agências internacionais associadas às grandes empresas de notícia, como Life, Time, Associated Press, mas também por agências independentes como a francesa Magnun, levou a uma guerra de imagens permeada pelas posições opostas no campo político, em favor ou contra a guerra.

No front da guerra do Vietnã, a prática fotográfica dos fotógrafos apoiava-se no ideal de testemunha ocular da história e no uso da câmera fotográfica como olho da história - na expressão do fotógrafo americano Mathew Brady, que registrou os horrores da guerra de secessão americana no século XIX. Em 1960, os usos e funções da fotografia na cultura política americana acompanhavam as diferentes tendências em disputa, que englobavam tanto a defesa incondicional dos valores soberanos da democracia liberal quanto a crescente crítica humanista que encetou a juventude radical contra os sonhos de perfectibilidade e salvacionismo da América.

13 Para conferir um conjunto importante de registros sobre as manifestações pacifistas na Bay Area em San Francisco e Berkeley, acesse: <http://www.lib.berkeley.edu/MRC/pacificaviet.html $>$. 
Imagens que atestavam a dor humana em situações limite marcaram a cobertura fotográfica da guerra do Vietnã, migrando para o imaginário das diferentes e futuras guerras pelos meios da cultura visual, com grande destaque tanto para os filmes sobre a guerra do Vietnã quanto para os da Segunda Guerra, que foram contaminados pela experiência fotográfica no Vietnã. Os filmes movimentaram imagens fotográficas dando rosto e vida às dores humanas, enquanto signos em rotação circulavam em bottons fixados em camisetas, chapéus e blue jeans.
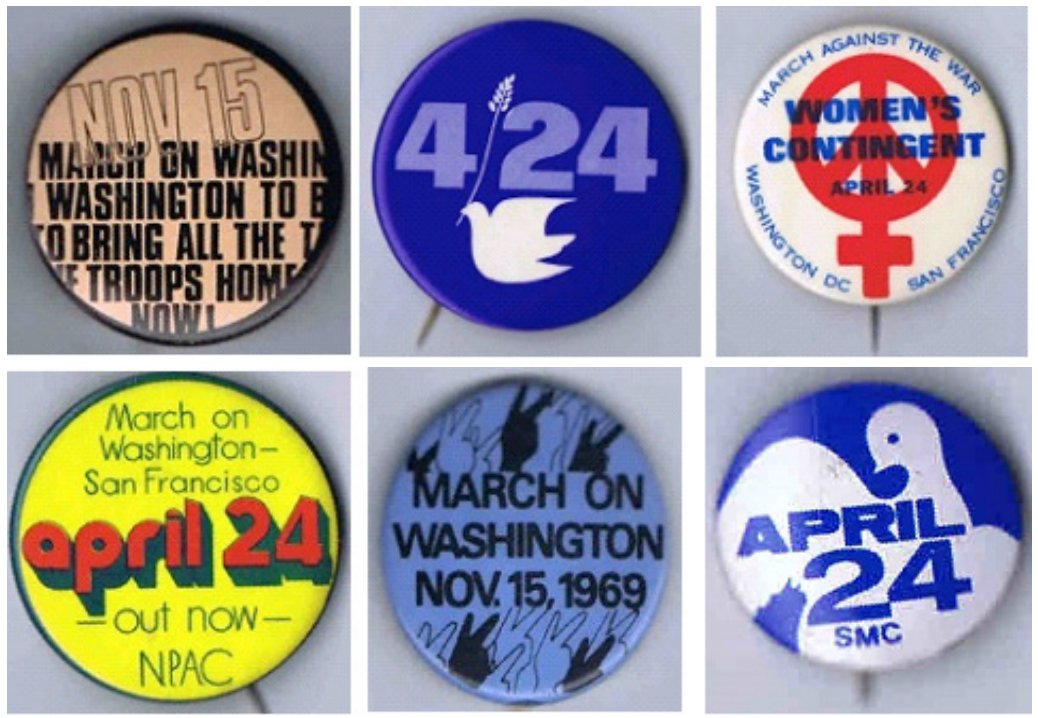

FIGURA 2.

Não vale enveredar pelo caminho das imagens que foram ao cinema, pois objetiva-se perseguir a imagem da flor, que, quatro anos depois do seu nascimento, em 1971, volta a acampar em Washington DC.

Entretanto, antes de continuar o rastreamento da flor nas imagens, há de se refletir sobre a noção de biografia ou trajetória de imagens no tempo. 


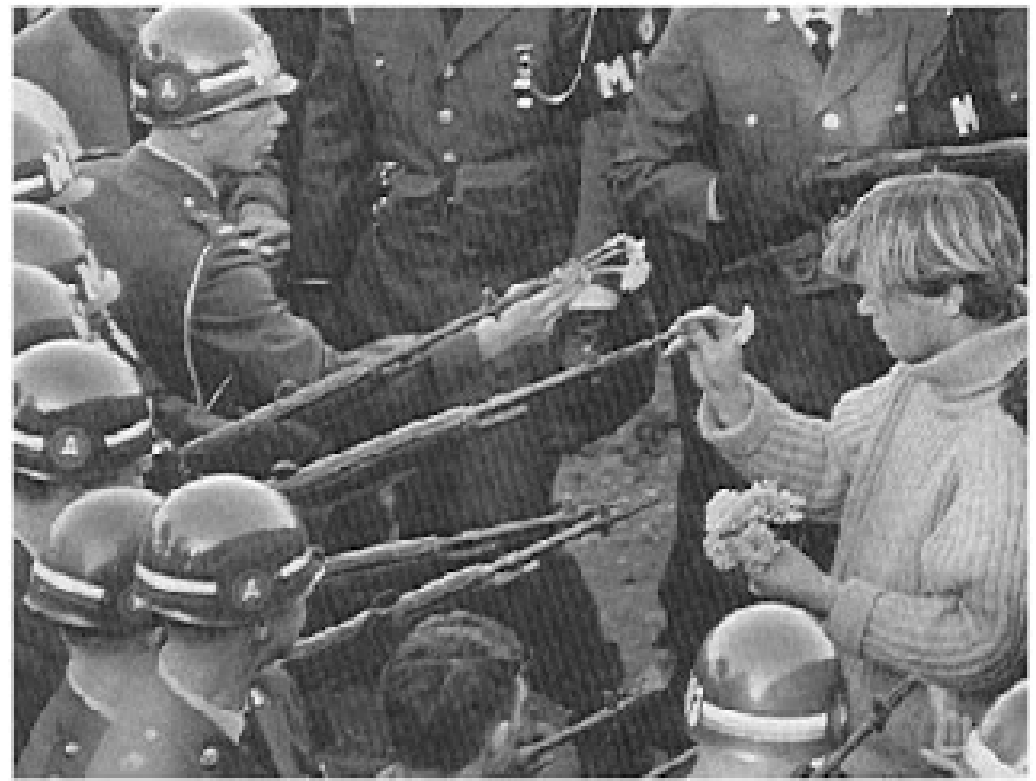

FIGURA 3 - MANIFESTAÇÃO CONTRA A GUERRA DO VIETNÃ, WASHINGTON DC, 1971.

\section{Em trânsito pela história, a vida social das imagens}

O historiador da arte alemão Hans Belting defende uma antropologia da imagem, em que antropologia caracteriza a condição corporal que se atribui a qualquer imagem. Belting propõe e sistematiza, em termos de tradição intelectual, uma epistemologia da imagem que considera o meio de sua materialização como parte integrante da construção do seu significado. Considera ainda que a forma, assim como a imagem, ao ser apropriada, ganha corpo. Efetivamente, considera a noção de prática como fundadora de experiência histórica com imagens por sujeitos, bem concretos e mundanos. Portanto, as imagens ganham corpo por meio de práticas sociais, em que sujeitos incorporam as imagens tanto como ideia e representação como objetos, marcas corporais e gestos. 
Belting propõe a tríade imagem-meio-espectador no desenvolvimento do estudo. Neste caso, não existe uma diferenciação da imagem em si - ontológica -, mas da imagem como relação epistemológica. Nessa perspectiva, a imagem não se descola do meio que a sustenta e fundamenta no processo de recepção e percepção, como explica o autor:

As imagens coletivas surgidas nas culturas históricas, incluindo-se a que pertencemos, proveem de uma antiga genealogia de interpretação do ser. Se as confundimos com as técnicas e os meios com os quais as invocamos na atualidade, se suprime uma distinção que ocupa um papel primordial na história das imagens [...] assim parece urgente plantear-se a questão do fundamento antropológico das imagens a partir da perspectiva do enfoque humano do artefato técnico. ${ }^{14}$

Compreende-se a produção das imagens como um ato simbólico e as imagens nascem da necessidade de simbolização. Trata-se de uma experiência histórica, pois as imagens se reciclam no processo contínuo de produção de sentido, daí a possibilidade de as imagens como símbolos acamparem em corpos diferentes e se tornarem novas imagens em novos processos de simbolização. Esse processo revela aspectos interessantes da sociedade que produz e recebe imagens. Em momentos diferentes, certas imagens, com sentidos comuns, entram em ação para animar valores e transformar o mundo onde os corpos habitam.

Assim, como nascem as imagens? Poderíamos dizer que da prática social de representar e simbolizar, pois nascem dos corpos que se projetam na imagem e das imagens que se animam nos corpos. A imagem existe em relação a um algo que a institui e, ao mesmo tempo, em que se refere a ela, pois:

Sua função é a de simbolizar a experiência do mundo e representar o mundo, de maneira que na transformação se indique também forçosamente a repetição. Por outro lado, a experiência da imagem expressa também uma mudança na experiência do corpo, o que faz com que a história cultural da imagem seja tam- 
bém de maneira análoga uma história cultural do corpo. [...] As imagens não nasceram no mundo por partenogênese. De fato, nasceram de corpos concretos da imagem, que deslanchavam o próprio efeito de seu material e formato. Não esqueçamos que as imagens tiveram a necessidade de adquirir um corpo visível, posto que eram objeto de rituais no espaço público oferecidos para a comunidade. Ademais, deviam ser instaladas em um lugar propício a sua apreciação, no qual se reuniam corpos que assim formavam um lugar público. ${ }^{15}$

A história das imagens, para evitar o essencialismo, valoriza a relação incontornável com os meios em que as imagens se agarram. Assim, Belting nos propõe como conceito central para a história das imagens a noção de intermedialidade, que "convoca imagens que conhecemos e recordamos de outros meios portadores e pressupõe a consciência da coexistência ou rivalidade entre distintos meios. Somente com os novos meios se pode observar características dos velhos meios que até então não tinham sido percebidas". ${ }^{16}$

Portanto, uma antropologia da imagem em Belting

enfrentará o reconhecimento de que todas as imagens convocam, continuadamente, imagens novas e distintas, dado que as imagens só podem ser respostas ligadas com a sua época, e já não poderiam satisfazer os questionamentos da geração seguinte. [...] Qualquer imagem só poderá ter efeito de nova porque se utiliza de um novo meio, ou porque reage a uma nova práxis de percepção. ${ }^{17}$

No caso da fotografia, há uma identificação automática entre objeto-mundo e o objeto-imagem. A fotografia realiza a mediação entre sujeitos históricos e o mundo visível - o mundo que se formata nas memórias, elaboradas por meio das imagens fotográficas -, uma forma histórica para dar forma ao mundo como imagem. As imagens não existem no mundo, precisam dos meios para existir. As imagens fotográficas, segundo Belting:

15 Ibidem, p. 30-33.

16 Ibidem, p. 63.

17 Ibidem, p. 73. 
São imagens simbólicas, imagens da imaginação, que percorreram um longo caminho antes de incursionar por este meio técnico. Se nos permite forçar um pouco o assunto, o questionamento está dirigido prioritariamente às vertentes das imagens dentro das fotografias. A fotografia, o meio moderno de imagens conseguidas de forma automática, funciona dentro desta perspectiva como um novo espelho, no qual aparecem as imagens do mundo. A percepção humana sempre se adequou às novas técnicas da imagem, mas transcende as fronteiras próprias dos meios que a conformam. As próprias imagens são intermediais: continuam transitando por meios históricos e inventados para elas. As imagens são nômades de meios. Desmontam seu acampamento em cada novo meio em que se estabelecem na história das imagens, antes de mudar-se para o meio seguinte. Seria um erro confundir as imagens com os meios. Os próprios meios são um arquivo de imagens mortas, que somente animamos com o nosso olhar. ${ }^{18}$

A fotografia, assim concebida como forma de olhar o mundo pelos olhos da modernidade - um meio técnico de dar forma ao mundo por meio de imagens - é uma imagem ato - uma reserva de memória - o arquivo do mundo. Diferencia-se, portanto, do rastro e da cópia. Por meio da fotografia nos separamos do mundo e, através dos múltiplos e plurais percursos, aprendemos a olhá-lo. A antropologia da imagem de Belting nos apresenta dois caminhos dentro da multiplicidade, sem cair na duplicidade, pois cada polo desse jogo evoca e compreende outros polos. Assim, tem-se o olhar do produtor e o olhar do espectador. $\mathrm{O}$ olhar do produtor percorre o trajeto das imagens do passado que lhe informa a ação e se define numa prática; o olhar do espectador, afetado pela presença das imagens na foto, percorre o trajeto que parte das imagens apresentadas e ruma para imagens imaginadas e projetadas, reage ao jogo de semelhanças difusas com outras imagens. Empresta, assim, um novo ânimo às imagens que, ao serem condensadas na fotografia, teriam perdido a vida.

O mundo só se torna imagem num processo de medição:

Não adiantou nada apontar a câmera para o mundo: lá fora não existem imagens. Unicamente no nosso interior a elaboramos 
sempre $[. .$.$] Quando a fotografia se adequou à pintura, não foi$ uma simples mimese entre dois meios, pois historicamente alçou-se a pintura à condição por excelência de produtora de imagens. Portanto, o que se imitava não era a pintura, mas a eficácia das suas imagens. ${ }^{19}$

Do ponto de vista antropológico, a fotografia revelaria uma experiência social, estética e existencial dos sujeitos com o mundo - não se trata de discurso, mas de uma forma ótica de dar a ver o mundo com maior precisão visual que os nossos olhos. Portanto, representa o meio que intercalamos entre nós e o mundo:

[...] o mundo se transformou diante de nossos olhos depois de fotografado. [...] A fotografia geometriza, nivela e classifica. Os lugares se tornam lugares fotografados e, como tais, se encontram fechados no retângulo da tomada fotográfica sem poder escapar do empirismo, mas a mudança está confinada a um tempo que pertence ao passado.[...] Atualmente contamos com um arquivo de fotografias que não somente recordam a época em que foram tiradas, mas também fazem recordar o motivo pelo qual foram tiradas. O motivo permanece em um tempo perdido e com ele envelhece. [...] o mundo permanece na fotografia unicamente da maneira que unicamente foi ${ }^{20}$

No jogo de produção e consumo de imagens, a fotografia caracteriza-se como revelação, objetivação do mundo visível, mas dotada de subjetividade, pois demanda a presença de sujeitos que a animem. A fotografia é uma espécie de reserva de memória, de arquivo onde se realizam buscas que traçam os percursos do olhar:

O mundo na fotografia se converte em um arquivo de imagens. O perseguimos como se fora um fantasma e somente o possuímos nas imagens, das quais sempre escapou. Também as imagens fotográficas permanecem como lembranças mudas de olhares anteriores. Somente as animamos quando nos tra-

19 Ibidem, p. 267.

20 Ibidem, p. 268. 
zem de volta nossas próprias lembranças. Os olhares de dois espectadores diante da mesma fotografia divergem, na mesma medida em que divergem as lembranças. O olhar "recordante" do espectador atual é diferente do olhar recordado que conduziu até a fotografia, e nela se coisificou. No entanto, a aura de um tempo que não se repete deixou seu rastro em uma fotografia irrepetível e nos conduz a uma animação peculiar, que produz um estado de harmonia afetiva no espectador. A diferença entre imagem e realidade, na qual se radica o enigma de uma ausência tornada visível, regressa na fotografia através da distância em relação ao tempo que chega "post factum" até nossos olhos. Apesar de na fotografia confundirmos "a lógica da mimese" e a analogia, que é de natureza metafórica, com a lógica do contato e do rastro, que pertence à metonímia, é impossível separá-la do ato que a produziu; é uma image-act, ou seja, um corte agudo tanto no sentido espacial quanto temporal. ${ }^{21}$

A fotografia é sempre pensada como síntese de imagens, em que outras imagens se encontram e promovem a autonomia do meio. Portanto, no espaço da fotografia se promove o encontro de olhares em tempos distintos e com tempos distintos. Por exemplo, as imagens de um mesmo tema na pintura migram para a fotografia acentuando as distâncias temporais, ou, ainda, para marcar a diferença de duração entre formas de simbolização. Portanto, ao se tomar a foto na relação proposta por Belting (imagem-meio-corpo), avalia-se a dimensão temporal na e da foto não somente como resultado de um dispositivo técnico, mas, sobretudo, de uma experiência vivencial:

Não podemos mais considerar a câmara como o meio de um olhar que se fixa na imagem, tomando em conta que se trata de um olhar estranho que se transfere ao nosso próprio olhar quando nos colocamos diante da imagem final. A percepção simbólica que empregamos quando estamos diante de fotografias consiste num intercâmbio de olhares. Lembramos o olhar que por sua vez é recordado na foto. Neste sentido, a fotografia é um meio entre dois olhares. Por isso resulta importante considerar o tempo que transcorreu entre o olhar capturado e o olhar que reconhece. Vemos o mundo através de outro olhar, não obstante lhe concedemos o que poderia ter sido nosso próprio olhar. 
No entanto, o mesmo mundo se vê distinto, pois foi visto em outra época. Olhamos o mundo em uma imagem que não foi inventada e que, ao mesmo tempo, outorga duração ao olhar com o qual também realizamos nossas vivências do mundo (o olhar também é histórico). ${ }^{22}$

A relação entre fotografia/imagem e mundo é a base pela qual Belting vai compor a antropologia da imagem, como epistemologia das mediações criativas entre o sujeito dotado de um corpo e os meios que se utiliza para transformar o mundo em imagens. Neste caso, é importante destacar o sentido que Belting atribui à autoria, onde defende que essa só se realiza quando os fotógrafos se liberam do fato visual e assumem a intencionalidade do gesto de armar a cena, montar a imagem, imaginar e prever: com isso, o mundo se converte em matéria de imaginação; essa atitude só pode existir quando a fotografia revela seu estatuto de meio e se questiona como meio... torna-se uma forma de arte. Ou, como queria Agambem, quando fotógrafo e fotografado lançam-se no jogo de existir nos rastros das experiências históricas. ${ }^{23}$

Belting nos fornece um interessante roteiro teórico para pensar esse trânsito de imagens pela história, num vaivém que identifica em cada nova imagem que nasce aquela que a gerou. Assim, de posse desse mapa teórico, seguimos a trajetória da imagem rumo ao futuro - protestos de 2013, em que a imagem da moça e da flor montou acampamento para gerar novas imagens.

\section{De volta ao futuro - 2013 imagens acampadas nas praças e ruas}

Em junho de 2013, as cidades do Brasil, em sintonia com outras cidades em outras partes do mundo, foram palco de manifestações contra a ausência de ser contra. $O$ ponto de partida foi o aumento de passagens

23 AGAMBEM, Giorgio. O autor como gesto. In:____. Profanações. São Paulo: Boitempo, 
de ônibus, desdobrando-se em ondas de protesto contra a FIFA, a copa do mundo, numa inusitada rebeldia contra o caráter inato do brasileiro cordial, amante do samba, das mulatas e do futebol. Na primavera outonal das cidades do Brasil, imagens floresceram nas ruas, acampadas no espaço virtual das redes sociais, dos blogs e jornais on-line, ganharam corpo em jornais impressos e vida no impacto proporcionado pela repercussão na opinião pública.

Em tais imagens, meninas, meninos, flores e policiais compuseram o quadro de uma anunciação - arcanjos Gabriel surgiram frente às autoridades constituídas para trazer a boa nova. O que nos leva de volta ao passado.

\section{De volta ao passado - onde nascem as imagens? A descoberta de uma imagem}

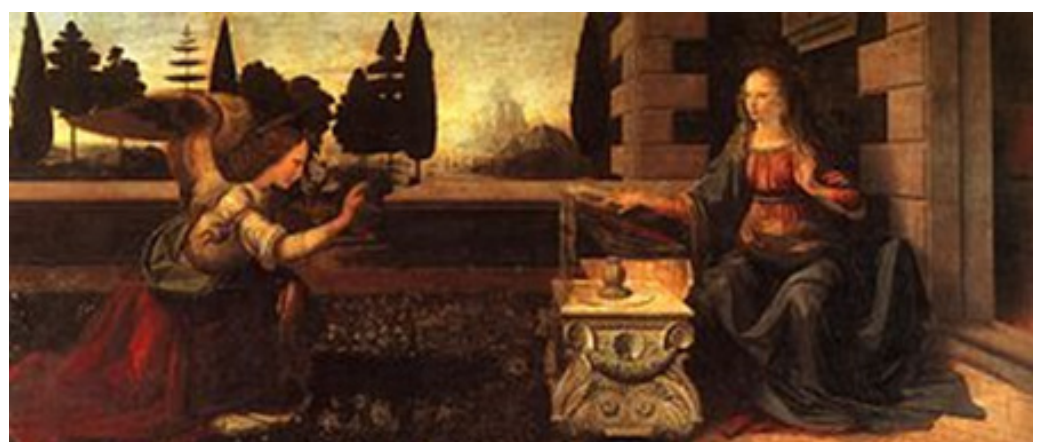

FIGURA 4 - ANUNCIAÇÃO. POR LEONARDO DA VINCI, NA GALERIA UFFIZI, EM FLORENÇA. DISPONÍVEL EM: $<$ http://pt.wikipedia. org $/$ wiki/Anuncia $\% \mathrm{C} 3 \% \mathrm{~A} 7 \% \mathrm{C} 3 \% \mathrm{~A} 3 \mathrm{o}>$.

A Anunciação, um dos mais frequentes temas da arte cristã, tanto no oriente quanto no ocidente, principalmente durante a Idade Média e o Renascimento, figura no repertório de quase todos os grandes mestres. As imagens da Virgem Maria e do Anjo Gabriel, emblemáticas da pureza e da graça, foram temas favoritos na arte mariana católica romana. 
No Renascimento, as imagens litúrgicas relacionam a narrativa bíblica a uma forma figurativa que segue os preceitos estéticos da configuração de novo espaço plástico, característico ao Quatrocento. Entretanto, como observa o estudioso francês Pierre Francastel, na linha de uma sociologia da arte:

O espaço não é uma realidade em si, da qual somente a representação é variável segundo as épocas. O espaço é a própria experiência do homem. É tão só porque séculos de convenção habituaram-nos a aceitar determinados signos expressivos utilizados na educação, com o fito de desenvolver simultaneamente nossas faculdades matemáticas e nossas faculdades visuais, que nos parece evidente que determinada perspectiva euclidiana fornece-nos, de modo espontâneo, a ilusão perfeita da realidade. Aceitar essa tese é admitir que o mundo exterior é um objeto em face do qual encontra-se o homem de todos os tempos e de todos os países; é admitir também que uma época, a do Renascimento, descobriu de alguma maneira uma das chaves que lhe permitem de uma vez por todas demonstrar os segredos do universo através da análise e da representação de certas estruturas de tal forma privilegiadas, que constituem, depois da revelação cristã, uma espécie de nova revelação natural - que o tempo concilia mais ou menos perfeitamente com o precedente [...] Pode-se perfeitamente admirar o impiedoso sistema de seleção que o Renascimento constitui e contatar, ao mesmo tempo, seu caráter arbitrário, recusar-se a ver nele a regra intangível de qualquer representação plástica bela e sugestiva.[...] O espaço do Renascimento não é um sistema habilidoso de representação de determinados valores imutáveis, ou, antes, dos únicos valores imutáveis da visão. Ele é um sistema perfeitamente adaptado a uma certa soma de conhecimento. ${ }^{24}$

Nessa linha de reflexão, associa-se a experiência social do espaço à representação plástica do mundo que, absolutamente, não se reduz à criação de fórmulas e métodos para representar de forma realista o que se vê no mundo, mas em elaborar um sistema mental de representação que conteria, além dos próprios elementos figurativos, elementos intelectuais, emotivos

24 FRANCASTEL, Pierre. Pintura e Sociedade, São Paulo: Martins Fontes, 1990. p. 24-27. 
e sentimentais. Trata-se de visualizar um conjunto de representações que são tanto morais - atribuidoras de valor - quanto objetivas. O novo sistema fundamenta-se, sobretudo, mais na sua significação social ou prática do que em princípios matemáticos. Assim, explica Francastel,

se admitimos que o espaço não é uma realidade em si, permanente e exterior ao homem, temos de compreender que, em sua experiência contemplativa ou ativa do mundo, o homem introduz, ao mesmo tempo, valores positivos e imaginados. $\mathrm{O}$ espaço do Renascimento não é uma espécie de contexto vazio determinado apenas por uma rede de linhas geométricas; ele implica a presença de objetos e de imagens. ${ }^{25}$

Podemos complementar a reflexão de Francastel com anotações que Belting faz sobre a criação das imagens com o Renascimento. Um dos pontos importantes destacados pelo autor é o papel desempenhado pela pintura na delimitação da noção de enquadramento, isso porque a própria tela delimitava o espaço de varredura do olhar e os recursos que o meio pictórico oferecia para que o espectador se lançasse no quadro. Por exemplo, o uso do recurso de "janela", para projetar um espaço exterior e imaginado como alternativa à clausura do espaço emoldurado, ou, ainda, o recurso ao esquadrinhamento dos elementos figurativos no espaço da representação com recursos visuais para criar o efeito de profundidade. Em ambos os exemplos, tratava-se de um meio para o olhar, e não um meio para o corpo, diferença fundamental para, segundo Belting, o conceito de imagem da Modernidade.

Assim, ainda seguindo esse autor, de uma maneira diferente do livro impresso, a pintura se converteu em meio transmissor da cultura ocidental e não somente da arte:

O espectador exercitava aqui somente seu próprio olhar para o mundo, mas também a expansão de sua imaginação. Dado que a pintura é um meio ocidental, encontrou seu lugar histórico não somente na arquitetura ocidental, com suas antíteses de espaços interiores reformados e vistas de janela, mas também 
na concepção ocidental do sujeito, que se percebe antitético em sua relação com o mundo. A pintura exigia um esforço de abstração por parte do espectador que exercitara nesse meio seu olhar para o mundo, dado que negava sus própria superfície para simular atrás um espaço virtual que na projeção do espectador se colocava no lugar da experiência. Aqui poderia falar-se já de um meio incorpóreo que transladava o mundo corporal a uma imagem. ${ }^{26}$

Belting ainda observa que, apesar de a fotografia ter continuado o campo visual definido pelo enquadramento pictórico, separou-se radicalmente do tipo de imagem da pintura, porque deixou de ser um meio do olhar para tornar-se um meio do corpo que criava a sua marca de presença. Entretanto, reflete Belting:

com o transcurso do tempo, esta sombra se separava do corpo, como fazem todas as imagens. A sombra surgiu no momento da iluminação, mas perdeu o corpo no momento em que entrou em contato com os olhos dos espectadores. Na imagem fixa, o movimento da vida ficava congelado, como se tratasse de uma lembrança perdida, o que a distingue, na cultura ocidental, das imagens representadas que, em outras culturas, permaneceram ligadas por mais tempo ao ritual em movimento ou da dança. ${ }^{27}$

No quadro da Anunciação, revela-se o lugar onde uma imagem nasce como resultado de uma prática de representação visual da narrativa bíblica. Elabora-se no Renascimento um pensamento plástico sobre a experiência religiosa, que traduzia valores em cenas litúrgicas como forma de educar e de cultivar o olhar. Se tomarmos as afirmações de Francastel e, principalmente, de Belting, podemos observar um conjunto de reminiscências que se atualizam a cada novo meio-imagem.

A descrição que E. H. Gombrich faz da peça Anunciação, produzida no século XIV pelos artistas Simone Martini e Lippo Memmi (1333), conjuga elementos fundamentais para a compreensão desse processo de representação.

26 BELTING, op. cit., p. 55.

27 Idem. 


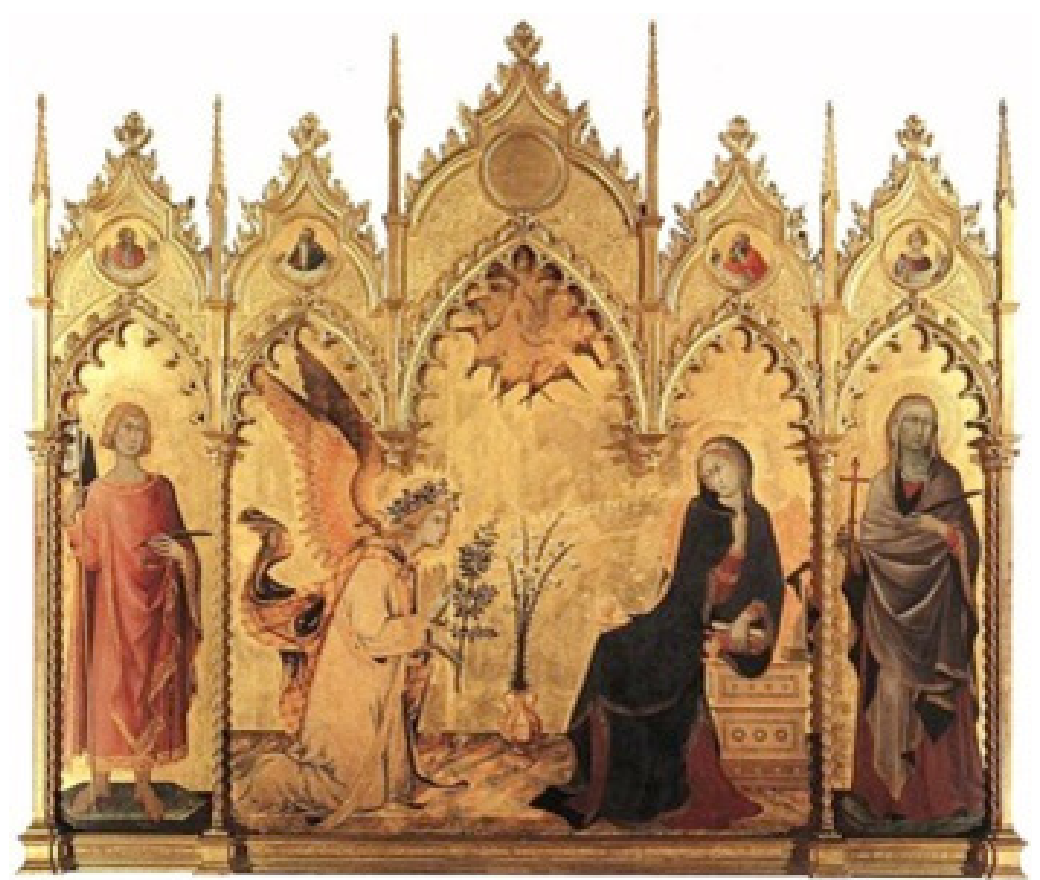

FIGURA 5

A obra mostra em que grau os ideais e a atmosfera geral do século XIV tinham sido absorvidos pela arte de Siena. A pintura representa a Anunciação - momento em que o Arcanjo Gabriel chega do Céu para saudar a Virgem, e podemos ler as palavras que saem da sua boca: "Ave gratia plena". Em sua mão esquerda segura o ramo de oliveira, símbolo da paz; a mão direita permanece erguida como se ele estivesse prestes a falar. A virgem estava lendo. A aparição do anjo colheu-a de surpresa. Entre os dois está um vaso de açucenas, símbolo de virgindade, e no alto do arco ogivado central vemos a pomba, símbolo do Espírito Santo, cercada de querubins de quatro asas [...]. De fato, a pintura se assemelha a um preciso trabalho de ourives, com suas figuras destacando-se de um fundo dourado, tão habilmente organizadas que formam um padrão admirável. Não nos cansamos de admirar o modo como essas figuras são encaixadas no 
complicado formato dos retábulos; a maneira como as asas do anjo são emolduradas pelo arco ogival da esquerda, e a figura da virgem se retrai para ficar emoldurada pelo arco da direita, enquanto o espaço vazio entre as duas figuras é preenchido pelo vaso e pela pomba que paira em cima dele. Os pintores tinham aprendido da tradição medieval essa arte de ajustar as figuras a um determinado padrão [...] Mas sabemos que eles assim procederam por ignorarem o formato e as proporções reais das coisas, e esqueceram totalmente os problemas de espaço. Não era esse o método dos artistas de Siena. Talvez achemos suas figuras um pouco estranhas, com seus olhos oblíquos e bocas curvadas. Mas bastará examinarmos alguns detalhes para ver que os ensinamentos de Giotto não estavam sendo desperdiçados, em absoluto. O vaso é um vaso real, colocado num chão real de pedra, e podemos dizer exatamente onde ele se encontra em relação ao anjo e à virgem. $\mathrm{O}$ banco da Virgem é um banco de verdade, recuando em direção ao plano de fundo, e o livro que ela segura não é apenas o símbolo de um livro, mas um genuíno livro de orações, a luz nele incidindo sobre as páginas, o que deve ter sido estudado pelo artista com base num livro de orações em seu ateliê..$^{28}$

$\mathrm{Na}$ descrição se apresentam os elementos temáticos associados à história da vinda do Messias - o anjo Gabriel e a Virgem Maria; elementos figurativos; a forma como a representação do espaço se organiza no marco da tela, voltado para a elaboração de representação visual realista, em que o sujeito do olhar e o espectador que olha se identificam em um mesmo corpo; e os elementos axiológicos relativos aos valores que, no século XIV, se atribuíam a esse evento, dentre os quais: a noção de espanto, surpresa, boa nova e paz. Essa imagem nasce em um meio pictórico, mas se descola dele ganhando vida, novamente, na fotografia de Marc Riboud. Desta vez, animados não pela contemplação piedosa dos espectadores do século XIV, mas por uma opinião pública engajada contra a guerra que toma a imagem como bandeira desfraldada através do tempo, tornando-se um foto-ícone dos protestos pacíficos. 
De volta ao futuro - o que anunciam as imagens dos protestos dos 60's e de 2013?

Nasce assim uma nova imagem, irmã da primeira, mas tributária de uma outra cultura visual e política, na qual se preservam os valores de esperança, paz e mudança, mas que são descartadas as noções de pureza, piedade e passividade, que, por sua vez, se transmutam nas formas de tradição, ordem e repressão. Num jogo claro de entre imagens e entremeios, a intervenção lúdica da arte evidencia essas transmutações de sentido.
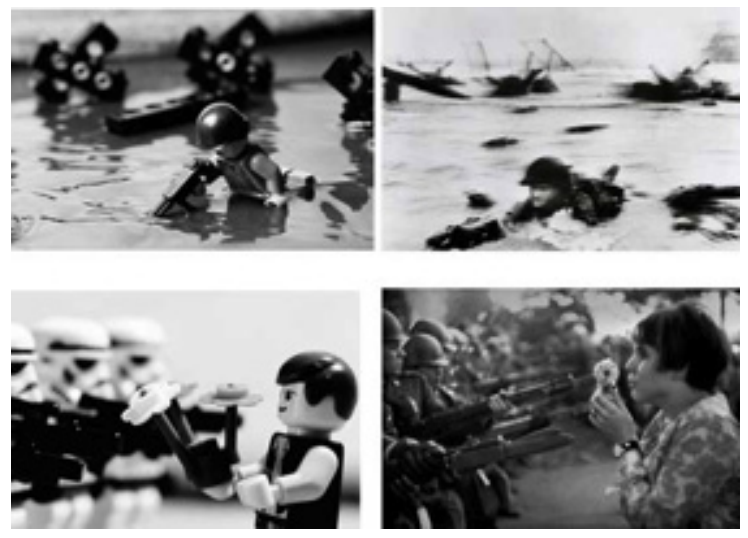

FIGURA 6 - EXERCÍCIOS DE "LEGOFOTOGRAFIA". DISPONÍVEL EM: $<$ http://www.chilloutpoint.com/featured/classic-photography-recreated-using-legos.html>.

Por outro lado, entre a imagem matriz de 1967 e as que nasceram em 2013, algumas observações devem ser feitas. Embora se tenha mantido o 
eixo temático em torno do protesto pacífico, observam-se algumas mudanças importantes no espaço figurativo. A primeira delas é que o meio no qual a imagem acampa é virtual, não mais analógico, o que desloca o realismo da imagem para o espectador que, necessariamente, deve não só identificar o contexto, mas sentir-se, ele também, participante do evento virtual. $\mathrm{O}$ espaço virtual ganha corpo nos espaços públicos das ruas e praças mundo afora. Observa-se também um novo ordenamento dos elementos da foto, ora valorizando o gesto, ora o indivíduo, a flor ou a própria experiência estética de fotografar, cada qual jogando com diferentes valores que estão sendo acionados na arena política dos movimentos sociais e coletivos hoje.
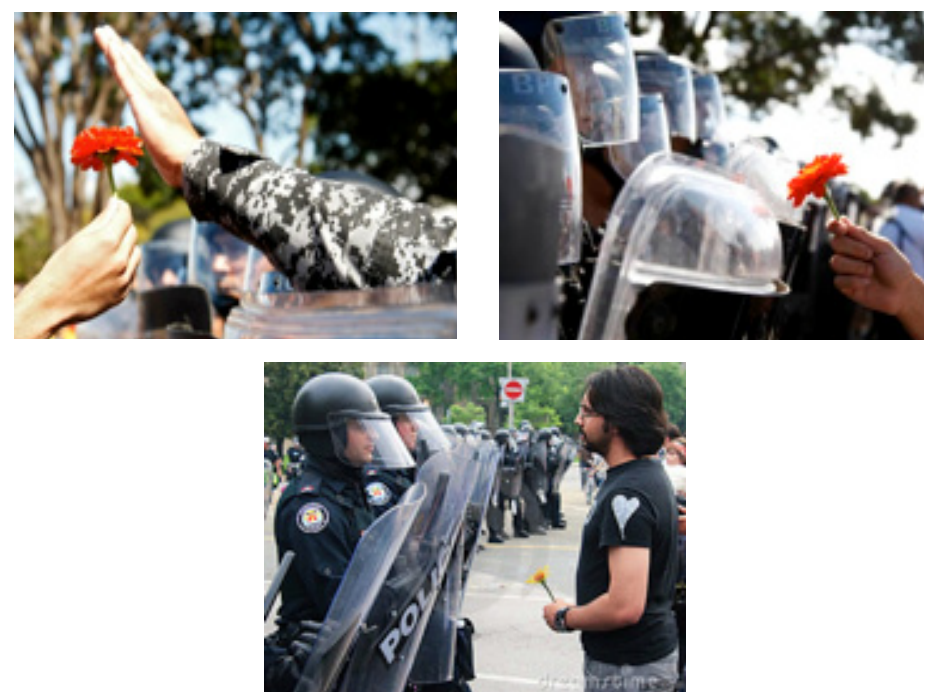

FIGURA 7 - DISPONÍVEL EM: <http://blogs.calgaryherald.com/2013/06/ 19/confederations-cup-2013-photos-protests/>.

Dessa iconosfera criada pela visualidade dos protestos de 2013, quero destacar, principalmente, a fotografia que ilustrou uma crônica publicada na seção "Imaginação", do Caderno Ilustríssima, do jornal Folha de São Paulo, de 23 de junho de 2013 (p. 12). Esta parte do caderno é voltada para a "prosa, poesia e tradução" e a relação texto e imagem revela aspectos interessantes sobre a biografia dessa imagem. 


\section{IMAGINACAO I FAIS EM PROTESTO}

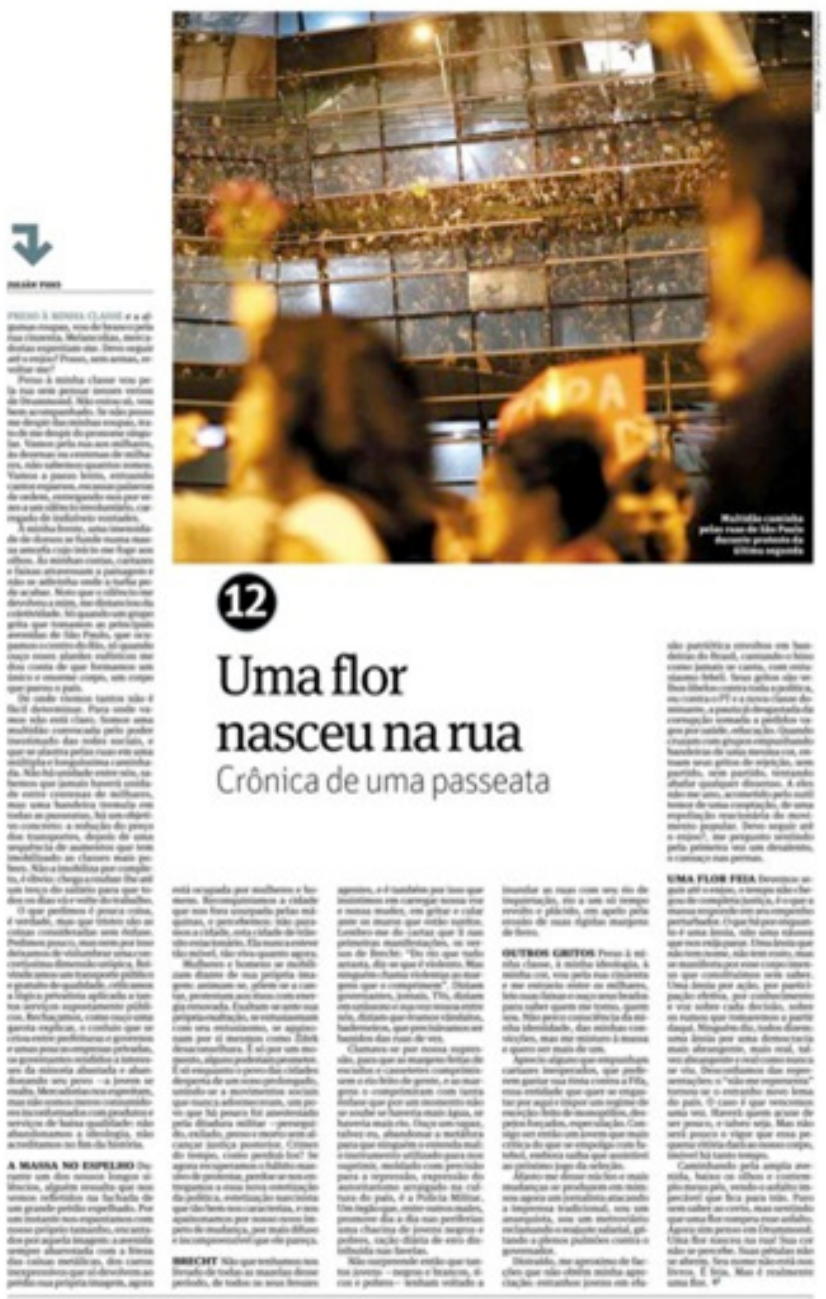

FIGURA 8. 
O texto, uma crônica assinada por Julián Fuks, escritor paulistano nascido em 1981 e repórter de literatura da Folha. A fotografia, do fotógrafo paulista Fábio Braga, nascido em 1980 e que trabalha para o grupo Folha desde 2009. Ambos jovens e sintonizados aos acontecimentos de junho de 2013. Em cada um dos meios - textual e visual - acampam imagens que vagam pelas gerações, mas que ganham um sentido de novidade ao serem articuladas pela historicidade do presente.

$\mathrm{Na}$ crônica de Fuks, a passeata adquire o sentido de uma marcha contra o fim da história: "Mercadorias nos espreitam, mas não somos meros consumidores inconformados com produtos e serviços de baixa qualidade: não abandonamos a ideologia, não acreditamos no fim da história".

Na sequência do texto, se alude à imagem que o acompanha:

Durante um dos nossos longos silêncios, alguém ressalta que nos vemos refletidos na fachada do prédio espelhado. Por um instante nos espantamos com o nosso próprio tamanho, encantados por aquela imagem [...]. Mulheres e homens se mobilizam pela própria imagem: animam-se, põem-se a cantar, protestam-se aos risos com energia renovada [...] Se agora recuperamos o hábito massivo de protestar, perdoe se nos entregamos a essa nova estetização da política, estetização narcísica que tão bem nos caracteriza, e nos apaixonamos por nosso novo ímpeto de mudança, por mais difuso e incompreensível que ele pareça.

Escritor e fotógrafo se encontram projetados na imagem e imersos nos questionamentos e demandas da sua geração, nesse movimento recolhem imagens nômades que passeiam pelos tempos. O fotógrafo identifica a flor na multidão e a toma num primeiro plano desfocado, que a projeta no passado de onde veio.

Na conclusão da crônica, Fuks promove o encontro entre as flores. A flor da imagem visual encontra outra flor que acampou num outro tipo de imagem, como tema da poesia de Drummond:

Caminhando pela ampla avenida, baixo os olhos e contemplo os meus pés, vendo o asfalto impecável que fica para trás. Paro sem saber ao certo, mas sentindo que a flor rompeu esse asfalto. Agora sim penso em Drummond. Uma flor nasceu na rua! Sua cor não se percebe. Suas pétalas não se abrem. Seu nome não está nos livros. É feia. Mas é realmente uma flor (p. 12). 


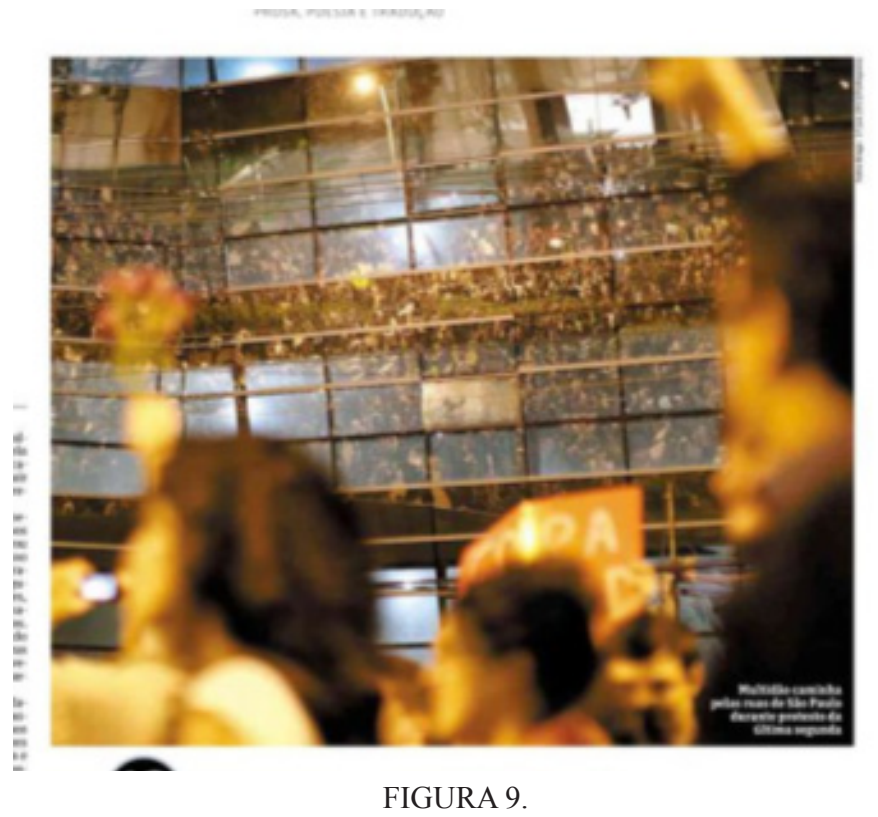

Nascida para ser devoção, essa imagem, que reúne no mesmo eixo narrativo flor, juventude e autoridade, não teria outro destino do que ser poesia, a forma síntese das experiências sensíveis.

\section{Considerações finais}

As imagens que acampam em corpos pelos tempos, foto-ícones que relampejam acontecimentos, registros digitais que condensam o cotidiano. Os múltiplos tempos da imagem, em seus mais diversos suportes, meios e corpos, se revelam na experiência fotográfica.

De acordo com Maurício Lissovsky, "toda fotografia é condensação de múltiplas temporalidades e sobrevivente de um naufrágio. Como toda sobrevivente, cada fotografia guarda em si a difícil pergunta sobre o propósito de sua sobrevida, a pergunta sobre o que nela, a despeito de tudo o que 
passou, ainda será". ${ }^{29}$ Nessa trilha, ao biografar fotografia de Marc Riboud produzida em Washington DC, em 1967, descobrem-se na sua linhagem as transmutações de sentido próprias à passagem das gerações. Dos sentidos próprios à liturgia religiosa e ao domínio da cultura visual apoiada na expectação como adoração, para outro tipo de liturgia de natureza política amparada pela atuação ativa do espectador, também ator dos acontecimentos figurados. Paralelamente, a imagem da flor migra dos espaços das igrejas e capelas reais, de natureza reservada a uma ordem onde o político e o religioso imiscuem-se, para o espaço das praças públicas alçadas pelas revoluções modernas como referência de espaço comum.

A imagem que nasceu para ser adorada tornou-se um foto-ícone onde os ideais de democracia participativa ganhariam a sua forma visual, mais bem acabada. Tanto que, em 2013, sua descendência mais uma vez retoma a praça pública, o espaço da civitas, para animar os corpos que se mobilizam e afetam pelas imagens. A flor que nasce nas praças e ruas do mundo contemporâneo compõe uma imagem dialética que comporta poesia e política.

Entretanto, podem reclamar os mais aguerridos que imagens poéticas não derrubam sistemas de governo, não alimentam os famintos, não proporcionam melhorias no sistema de saúde. Para os quais respondemos: imagens poéticas fornecem sentido às ações coletivas, criam memórias das gerações, atribuem valor ao que parece ordinário mas, sobretudo, conseguem transformar expectativa em esperança.

Talvez, nas imagens poéticas que acampam nos protestos mundo afora, se elaborem novas formas de conceber a ordem do tempo, em que o passado possa ter um futuro e o futuro não faça tábula rasa de seu passado. Talvez, um novo regime de historicidade que assuma as imagens não só como tema de uma história das representações, mas como plataforma de observação privilegiada da experiência histórica. Nesse novo tempo, há que se enfrentar o desafio, já apontado pelo historiador Paulo Knauss ${ }^{30}$, de se escrever a história com imagens.

Recebido em: 29/04/2014

Aprovado em: 03/07/2014

29 LISSOVSKY, op. cit., p. 8.

30 KNAUSS, Paulo. O desafio de fazer História com imagens: arte e cultura visual. ArtCultura, Uberlândia, v. 8, n. 12, p. 97-115, jan.-jun. 2006. 